ORIGINAL ARTICLE

PRACA ORYGINALNA

\title{
COGNITIVE DISORDERS IN PERSONS OF WORKING AGE WITH DYSCIRCULATORY ENCEPHALOPATHY
}

DOI: 10.36740/WLek202003107

\author{
Olena V. Litvin', TetianaV. Chernii', 0 lga Ye. Kovalenko ${ }^{1,2}$, Liliana V. Klymenko ${ }^{2}$, Nina 0. Perederii ${ }^{3}$ \\ 'STATE INSTITUTION OF SCIENCE "RESEARCH AND PRACTICAL CENTRE OF PREVENTIVE AND CLINICAL MEDICINE» STATE ADMINISTRATION \\ DEPARTMENT, KYIV, UKRAINE \\ 2P. L. SHUPYK NATIONAL MEDICAL ACADEMY OF POSTGRADUATE EDUCATION, KYIV, UKRAINE \\ 3UKRAINIAN MEDICAL STOMATOLOGICAL ACADEMY, POLTAVA, UKRAINE
}

\begin{abstract}
The aim of the study was to study the neuropsychological features of cerebrovascular disorders in persons of working age at the outpatient clinic stage. Materials and methods: 90 persons of working age were surveyed. Clinical neurological and clinical instrumental examination.

Results: The first group consisted of patients with dyscirculatory encephalopathy on the background of arterial hypertension - 60 people, the second with dyscirculatory encephalopathy on the background of cerebral atherosclerosis - 30. Assessment of cognitive function was examined using the MMSE Mental Status Scale, Anxiety, and Depression Scale using the DASS-21 scale.

Conclusions: According to the results of the study, significant memory impairment on the MMSE scale $(p<0.003)$ was found in patients with dyscirculatory encephalopathy without arterial hypertension. In patients with dyscirculatory encephalopathy on the background of hypertension, anxiety $(p<0.001)$ and depressive disorders $(p=0.033)$ were significantly more prevalent compared with patients with dyscirculatory encephalopathy without arterial hypertension. The increase in depressive disorders and anxiety in patients with dyscirculatory encephalopathy on the background of arterial hypertension decreases orientation and memory.
\end{abstract}

KEY WORDS: hypertensive dyscirculatory encephalopathy, hypertension, memory, anxiety, depressive disorders

Wiad Lek. 2020;73(3):449-453

\section{INTRODUCTION}

Decreased cognitive function is one of the most common and socially significant disorders of the nervous system. A high level of cognitive and intellectual functions is a positive prognostic feature of life expectancy. Cerebrovascular pathology, neurodegenerative diseases and their combination are the main causes of cognitive deficit $[1,2,3$, 4]. Prevalence of cognitive disorders is associated with the current tendency to increase life expectancy and growth of the elderly people in the population, as well as to increase the occurrence of major risk factors for cognitive decline such as arterial hypertension, cerebral atherosclerosis and diabetes mellitus, which determines relevance of this problem for neurologists and doctors of other specialties [5].

Cardiovascular risk factor for cognitive impairment is metabolic syndrome, which includes: arterial hypertension, dyslipidemia, obesity, diabetes mellitus, impaired carbohydrate tolerance, underlying pathological mechanisms of cardiac and cerebrovascular disease. Recently, the prevalence of metabolic syndrome has been observed among able-bodied young and middle-aged people, which makes this problem extremely urgent $[6,7]$.
At present, arterial hypertension is considered as the most significant risk factor for the development of both acute and chronic disorders of the cerebral circulation, as well as disorders of memory and cognitive disorders. In many studies the relationship of persistent increase in blood pressure with the risk of progression of cognitive disorders has been proven [8]. Also, a large number of studies have shown that the predominance of dementia is a predominant increase in systolic pressure [7]. Chronic cerebral hypoperfusion due to increased vascular resistance in patients with hypertension may be a major factor in the development of dementia in hypertension. The brain is dependent on adequate oxygen and glucose delivery, and a decrease in cerebral blood flow impairs neuronal function, with possible subsequent brain damage [9].

The most common pathogenetic cause of cognitive impairment is the «small vessel disease» of the brain, which is more common in patients with hypertension and diabetes [10]. One of the substrates for the development of «small vessel disease» is atherosclerosis, which leads to the loss of smooth muscle cells tunica media, deposition of fibrogialin substances, narrowing the lumen and thickening of the vessel wall (lipogialinosis). In a more pronounced process, 
Table I. Frequency of cognitive impairment of varying degrees of expression on the MMSE scale.

\begin{tabular}{ccc}
\hline Index (in points) & $\begin{array}{c}\text { Patients with hypertensive } \\
\text { dyscirculatory encephalopathy, } \\
\mathbf{n = 6 0}(\%)\end{array}$ & $\begin{array}{c}\text { Patients with dyscirculatory } \\
\text { encephalopathy, } \\
\mathbf{n = 3 0}(\%) .\end{array}$ \\
\hline Dementia of moderate severity on the MMSE scale (11-19) & - & - \\
\hline Dementia of mild severity on the MMSE scale ( 20-23) & - & - \\
\hline Cognitive impairment on the MMSE scale (24-27) & $24(40)$ & $14(46,7)$ \\
\hline Normally, cognitive impairment is absent on the MMSE \\
scale (28-30)
\end{tabular}

Table II. Results of the MMSE study.

\begin{tabular}{cccc} 
& $\begin{array}{c}\text { Patients with hypertensive } \\
\text { dyscirculatory encephalopathy } \\
\mathbf{M ( Q 1 - Q 3 )}\end{array}$ & $\begin{array}{c}\text { Patients with dyscirculatory } \\
\text { encephalopathy } \\
\text { M(Q1-Q3) }\end{array}$ \\
\hline Orientation & $10(9-10)$ & $10(10-10)$ & 0,217 \\
\hline Memory & $3(3-3)$ & $3(2-3)$ & 0,003 \\
\hline Counting operations & $3(3-3)$ & $3(3-3)$ & 0,897 \\
\hline Overall cognitive performance & $28(26-28)$ & $28(27-28)$ & 0,597 \\
\hline
\end{tabular}

fibrinoid necrosis of the vascular wall leads to rupture of vessels and micro- or macro-hemorrhages, more often in the basal ganglia or thalamus [11].

Thus, the problem of chronic disorders of cerebral circulation and cognitive function in patients with hypertension is relevant in modern angioneurology. It should be noted that the number of patients with chronic disorders of the cerebral circulation, especially against the background of hypertension, is virtually none, which determines the relevance of the problem of further diagnosis and treatment.

\section{THE AIM}

The aim of the study is to study the neuropsychological features of cerebrovascular disorders in persons of working age at the outpatient clinic stage.

\section{MATERIALS AND METHODS}

Under our observation, there were 90 people aged 40 to 68 at the State Institution of Science «Research and Practical Centre of Preventive and Clinical Medicine» State Administration Department, Kyiv, Ukraine.

Patients were divided into two groups statistically comparable by major disease - dyscirculatory encephalopathy, sex and age. The first group consisted of patients with dyscirculatory encephalopathy and hypertension -60 people, the second with $\mathrm{DE}$ on the background of CAC 30. Among the examined patients in the first group were 17 men and 43 women. In the second group - 9 men and 21 women. The mean age of men in the first group was $51.54 \pm 0.76$, in the second $51.83 \pm 2.24$, women in the first group $54.63 \pm 0.42$, in the second $56.88 \pm 0.72$.

Clinical-neurological and clinical-instrumental examination was performed for all patients in order to establish the stage and form of vascular-brain pathology.
The study did not include patients with severe somatic pathology, clinically significant vascular events, and history of traumatic brain injury. Clinical and laboratory study included general blood test, biochemical blood test, lipidogram. Clinical and instrumental examination methods included electrocardiography, blood pressure measurements, and heart rate.

To assess patients' cognitive function, they used: a short MMSE mental status rating scale (determining time and place orientation, status of short-term, long-term memory, language, gnosis, praxis) [12]. According to the MMSE, 29-30 points were assessed as no cognitive impairment, 27-28 points were mild cognitive impairment, $24-26$ were moderate cognitive impairment, $20-23$ points were initial dementia, $<20$ were pronounced stages of dementia.

Anxiety and depression were examined using the Depression Anxiety Stress Scales (DASS-21) [13]. The survey found normal, mild, moderate, severe and very severe depression, anxiety, and stress.

\section{RESULTS}

Based on the history of complaints, anamnesis data, as a result of clinical and instrumental examination in 90 patients revealed a symptom complex that meets the criteria for the diagnosis of manifestations of cerebral circulation, among patients of the first group in 19 (31.7\%) were diagnosed dyscirculatory encephalopathy, stage I and in 41 patient (68.3\%) - stage II of dyscirculatory encephalopathy. In the second group in 10 patients $(33.3 \%)$ were diagnosed stage I of dyscirculatory encephalopathy and in 20 patients $(66.7 \%)$ - stage II. Arterial hypertension was observed in all patients in the first group. According to this classification $7(11.7 \%)$ patients had stage I hypertension and 53 $(88.3 \%)$ - arterial hypertension, stage II.

After conducting a neuropsychological test on the MMSE scale, $40 \%$ of patients with hypertensive dyscirculatory 
Table III. The results of the study on the scale DASS-21.

\begin{tabular}{cccc}
\hline & $\begin{array}{c}\text { Patients with hypertensive dyscirculatory } \\
\text { encephalopathy } \\
\text { M (Q1-Q3) }\end{array}$ & $\begin{array}{c}\text { Patients with dyscirculatory } \\
\text { encephalopathy } \\
\text { M(Q1-Q3) }\end{array}$ \\
\hline Stress & $11(9-14)$ & $11(10-15)$ & P \\
\hline Anxiety & $9(8-10)$ & $7(7-8)$ & 0,372 \\
\hline Depression & $9(8-10)$ & $8(8-9)$ & 0,001 \\
\hline
\end{tabular}

Table IV. Characterization of the correlation between the cognitive function on the MMSE scale and the indicators of emotional-volitional function on the DASS-21 scale in patients with hypertensive dyscirculatory encephalopathy.

\begin{tabular}{cccccccc}
\hline \multirow{2}{*}{ Indicators } & \multicolumn{2}{c}{ Depression } & \multicolumn{2}{c}{ Anxiety } & \multicolumn{2}{c}{ Stress } \\
\cline { 2 - 7 } & $\mathbf{r}$ & $\mathbf{p}$ & $\mathbf{r}$ & $\mathbf{p}$ & $\mathbf{r}$ & $\mathbf{p}$ \\
\hline Overall cognitive performance index & $-\mathbf{0 , 3 4 8}$ & $\mathbf{0 , 0 0 6 4}$ & $\mathbf{- 0 , 3 3 7}$ & $\mathbf{0 , 0 0 8 4}$ & $-0,073$ & 0,5782 \\
\hline Orientation & $-\mathbf{0 , 3 2 7}$ & $\mathbf{0 , 0 1 2 2}$ & $\mathbf{- 0 , 3 3 5}$ & $\mathbf{0 , 0 0 1}$ & $-0,17$ & 0,2008 \\
\hline Memory & $\mathbf{- 0 , 2 8 7}$ & $\mathbf{0 , 0 2 6 1}$ & $\mathbf{- 0 , 3 9 8}$ & $\mathbf{0 , 0 0 1 6}$ & $-0,154$ & 0,24 \\
\hline
\end{tabular}

$\mathrm{r}$ - Spearman rank correlation index.

Table V. Characteristic of the correlation between the cognitive function on the MMSE scale and the emotional-volitional function on the DASS-21 scale in patients with dyscirculatory encephalopathy.

\begin{tabular}{|c|c|c|c|c|c|c|}
\hline \multirow{2}{*}{ Indicators } & \multicolumn{2}{|c|}{ Depression } & \multicolumn{2}{|c|}{ Anxiety } & \multicolumn{2}{|c|}{ Stress } \\
\hline & $\mathbf{r}$ & $\mathbf{p}$ & $\mathbf{r}$ & $\mathbf{p}$ & $\mathbf{r}$ & $\mathbf{p}$ \\
\hline Overall cognitive performance index & $-0,324$ & 0,1319 & $-0,303$ & 0,16 & $-0,187$ & 0,3935 \\
\hline Orientation & 0,042 & 0,8505 & 0,025 & 0,9093 & 0,154 & 0,484 \\
\hline Memory & $-0,447$ & 0,0326 & $-0,367$ & 0,0849 & $-0,394$ & 0,0629 \\
\hline
\end{tabular}

$\mathrm{r}$ - Spearman rank correlation index.

encephalopathy and $47.8 \%$ with dyscirculatory encephalopathy were found to have cognitive impairment (Table I). A significant difference, on the MMSE scale, $p<0.003$ by Wilcoxon's W test in the two surveyed groups was observed in the memory study (Table II). In the study of memory, the incidence rate of X2 $=0.02$ significantly prevailed in patients of the first group - $15 \%$ of memory was assessed at 2 points, at $85 \%-3$ points. At the same time, $48 \%$ of patients in the second group had 2 points, $52 \%$ had 3 points.

The significant decrease in memory level was mainly due to the impairment of self-reproduction of information that was manifested in operational activities and training, while the memory of life events remained largely preserved. Such modal-nonspecific mnestic disorders with primary disorders of short-term memory in combination with fatigue and emotional instability indicate the defeat of the middle nonspecific structures of the brain at the level of the lower parts of the brain stem (I-th functional block of the brain according to Luriya AR [14].

It can be assumed that the irregularities of the calculus operations recorded initially are not related to organic changes of the frontal lobes of the brain (primary and secondary "frontal acalculia»), but depend on the lesions of the basal and medio-basal divisions of the frontal lobes of the brain (limbico-hippocampal system), which is known to lead to significant changes in the emotional sphere of the patient's behavior [15]. Defects of this type of intellectual activity - counting operations, in our category of patients arise on the basis of impulsivity and manifest themselves in violation of the orienting basis of action by reducing attention. Errors in them occur due to the acceleration of the flow of nervous and mental processes due to defects in the inhibitory processes [16] and/or cholinergic dysregulation [17].

After testing on the DASS-21 scale, it was found that mild depression was observed in 35\% of patients with hypertensive dyscirculatory encephalopathy, moderate anxiety in 50\%, severe anxiety in $16.7 \%$; in patients with dyscirculatory encephalopathy mild depression $-8.7 \%$, mild anxiety $-39.1 \%$. Significant difference on the DASS21 scale of anxiety $\mathrm{p}<0.001$ and depression $\mathrm{p}=0.033$ between the indicators of the two groups according to Wilcoxon's W criterion was shown in Table III.

Such changes in the level of anxiety should be associated, probably, with the recovery after treatment of neurohumoral balance: GABA-ergic inhibitory effects, serotonin, dopamine-peptidergic activation systems [18].

In most cases, the law of distribution of values was different from the normal one, so Spearman's rank correlation index was calculated for correlation analysis.

A negative correlation between the mean severity of depression and anxiety and overall cognitive performance $(\mathrm{r}=-0.348, \mathrm{p}=0.006),(\mathrm{r}=-0.337, \mathrm{p}=0.008)$ was found in patients with hypertensive dyscirculatory encephalopathy. As depression and anxiety increase, the overall cognitive performance index decreases. The negative correlation was 
found in the mean severity of depression and anxiety and orientation $(\mathrm{r}=-0.327, \mathrm{p}=0.01),(\mathrm{r}=-0.335, \mathrm{p}=0.001)$, respectively, with increasing depression and anxiety the orientation value decreases. Also, a negative correlation was found between the mean severity of depression and anxiety and memory $(\mathrm{r}=-0.287, \mathrm{p}=0.02),(\mathrm{r}=-0.398$, $\mathrm{p}=0.001)$, respectively, with increasing index depression and anxiety the value of memory decreases (Table IV).

Patients with dyscirculatory encephalopathy on the background of cerebral atherosclerosis revealed a negative correlation between the mean severity between depression and memory $(r=-0,447, p=0.03)$, the value of depression memory decreases (Table V).

\section{CONCLUSIONS}

1. Significant memory impairment on the MMSE scale ( $p<0.003)$ was found in patients with dyscirculatory encephalopathy without arterial hypertension compared with patients with dyscirculatory encephalopathy on the background of hypertension.

2. In the study of emotional and volitional disorders in persons of working age, it was proved that in patients with dyscirculatory encephalopathy on the background of arterial hypertension, anxiety $(\mathrm{p}<0.001)$ and depressive disorders $(\mathrm{p}=0.033)$ significantly outweighed compared with patients without arterial hypertension.

3. It is proved that the increase of the index of depressive disorders and anxiety in patients with dyscirculatory encephalopathy against the background of arterial hypertension decreases the index of orientation and memory.

\section{REFERENCES}

1. Bachinskaya N. Yu., Kopchak O. O. Holenergicheskaya strategiya v terapii kognitivnih narusheniy u pacientov pozhilogo i starcheskogo vozrasta [Cholenergic strategy in the treatment of cognitive impairment in elderly and senile patients]. International Neurological Journal. 2014; 2 (64): 84-92. (Ru)

2. Bachinskaya N. Yu. Lecheniye bolezni Alcheymera: sovremenniye vozmozhnosti I perspektivi [Treatment of Alzheimer's disease: current opportunities and prospects]. Neuro NEWS: psoneurology and psychiatry. 2011; 2/1: 14-23. (Ru)

3. Malev A. L, Tovazhnyanskaya E. L., Zaharova A. N. et al. Sovremenniy psihimenricheskiy analiz kognitivnih rasstroystv vsledsyviye sosudistih zabolevaniy golovnogo mozga [A modern psychometric analysis of cognitive upsets due to vascular diseases of the brain]. Medical psychology. 2014. 9/1 (33): 111-116. (Ru)

4. Bogdanov A. R., Bogdanov R. R., Mazok V. K. Et al. Kognitivniye narusheniya pri discirkulatornoy encefalopatiyi I ozhirenii. [Cognitive impairment in discirculatory encephalopathy and obesity]. Consilium medicum, 2015; 15(2): 46-51. (Ru)

5. Kim J. H. , Go S. M., Seo S. W. et al. Survival in Subcortical Vascular Dementia: Predictors and Probable Alzheimer's Disease in a Tertiary Memory Clinic Population. Dement. Geriatr. Cogn. Disord., 2015; 40 (3-4): 210-221.

6. Ciobica A., Padurariu M., Bild W. et al. Cardiovascular risk factors as potential markers for mild cognitive impairment and Alzheimer's disease. Psychiatr. Danub. 2011; 23 (4): 340-346.
7. Panza F., Solfirizzi V., Logroscino G. et al. Current epidemiological approaches to the metabolic-cognitive syndrome. J. Alzheimers Dis., 2015; 30 (Suppl.2): 31-75.

8. Treshchinskaya M. A. Arterialnaya hypertensiya i cerebrovaskularnaya patologiya [Arterial hypertension and cerebrovascular pathology]. News of medicine and pharmacy. 2009; 30-35. (Ru)

9. de la Torre J. C. Cerebral hemodynamics and vascular risk factors: setting the stage for Alzheimer's disease. J. Alzheimers. Dis. 2012;32(2):553-567.

10. Kovalenko 0. Ye. Ranni proyavi i dinamika rozvitku vertebralnobazilarnoyi discirkulacii, povyazanoyi z cervikovertebrogennoyu disfunkciyeyu ta napryami yiyi profilaktiki i likuvannya [Early manifestations and dynamics of the development of vertebral-basilar dyscirculation associated with cervicovertebrogenic dysfunction and directions of its prevention and treatment]. Medical work. 2004; 3/4: 46-53. (UA)

11. Faraco $G$., ladecola $C$. Hypertension: a harbinger of stroke and dementia. Hypertension. 2013; 62 (5): 810-817.

12. Folstein M.F., Folstein S. E., McHugh P. R. “Mini-mental state”. A practical method for grading the cognitive state of patients for the clinician. J. Psychiatr. Res. 1975; 12(3): 189-198.

13. Lovibond P.F, Lovibond S. H. The structure of negative emotion-al states: comparison of the Depression Anxiety Stress Scales (DASS) with the beck depression and anxiety inventories. Behav. Res. Ther. 1995; 33 : 335-342.

14. Zhirmunskaya S. A. Funkcionalnaya vzaimozavisimost bolshih polushariy mozga cheloveka (statisticheskiy analiz elektroencefalogram pri mozgovom insulte). [Functional interdependence of the cerebral hemispheres of a person (statistical analysis of electroencephalograms in cerebral stroke)]. Leningrad. Nauka. 1989; 130 p. (Ru)

15. Sotnikov P. I. Obzor metodov obrabotki signala elektroencefalogrami $\mathrm{v}$ interfejsah mozg-kompjuter [0verview of EEG signal processing techniques in brain-computer interfaces]. Engineering Herald. 2014; №10: 6120-632. (Ru)

16. Hohlova T. A. Osobennosti vnutri- I mezhpolusharnogo raspredeleniya kogerentnih svyazey pri vospriyatii inoyazichnoy rechi. [Features of intra- and interhemispheric distribution of coherent connections in the perception of foreign language speech]. Psychological research. 2015; 8: 4. (Ru)

17. Gordeyev S. A., Shvarkov S. B., Kovrov G. V. et al. Osobennosti funkcionalnogo sostoyaniya mozga i kognitivnih funkciy u bolnih vegetativnoy distoniyey v sochetaniyi s virazhennoy asteniyey [Features of the functional state of the brain and cognitive functions in patients with autonomic dystonia in combination with severe asthenia]. Annals of clinical and experiment. neurology. 2010; 4 (V.4):31-36. (Ru)

18. Melnikova T. S. Informativnost ispolzovaniya kogerentnogo analiza v psihiatrii [The information content of the use of coherent analysis in psychiatry]. Journal. «Functional diagnostics». 2009; 1: 88-93. (Ru)

The article is a fragment of the scientific research work «Development and improvement of methods of prevention of complications of arterial hypertension and coronary heart disease with concomitant diseases of the internal organs of government officials» (deadline - 2014-2018, state registration number 0114U002119).

\section{ORCID and contributionship:}

Olena V. Litvin - 0000-0002-5002-046X ${ }^{B, C, D}$

Tetiana V. Chernii - 0000-0002-0095-6091 ${ }^{\mathrm{A}}$ 
Olga Ye. Kovalenko - 0000-0002-5927-5565 ${ }^{E}$

Liliana V. Klymenko - 0000-0001-6749-113X A, F

Nina O. Perederii - 0000-0002-3856-3875 ${ }^{F}$

\section{Conflict of interest:}

The Authors declare no conflict of interest. .

\section{CORRESPONDING AUTHOR}

Olena V. Litvin

State Institution of Science

«Research and Practical Centre of Preventive

and Clinical Medicine» State Administration Department,

5 Verhnya str., Kyiv, Ukraine

tel: +38 0973997799

e-mail: litvinolena1970@gmail.com

Received: 17.01 .2020

Accepted: 05.03 .2020

A - Work concept and design, B - Data collection and analysis, C - Responsibility for statistical analysis,

D - Writing the article, $\mathbf{E}$-Critical review, $\mathbf{F}$ - Final approval of the article 